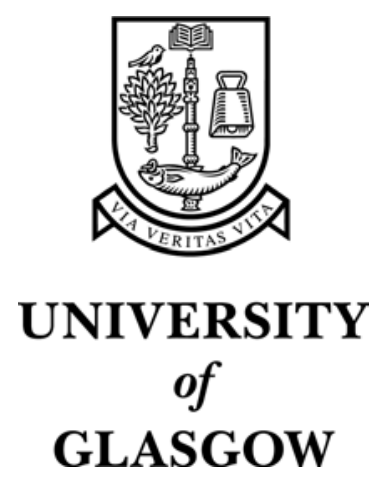

Knapp, A. B. (2000) Archaeology, science-based archaeology and the Mediterranean Bronze Age metals trade. European journal of archaeology 3(1):pp. 31-56.

http:/eprints.gla.ac.uk/archive/00002809/ 
Knapp-Archaeology and Science/EJA

\title{
ARCHAEOLOGY, SCIENCE-BASED ARCHAEOLOGY AND THE MEDITERRANEAN BRONZE AGE METALS TRADE
}

\author{
A. Bernard Knapp \\ Department of Archaeology \\ University of Glasgow \\ Glasgow G12 8QQ Scotland
}

Keywords: science-based archaeology, Cyprus, Sardinia, Mediterranean Bronze Age, metals trade, recycling, lead isotope analysis, social theory, commodification of metals

\begin{abstract}
Archaeologists often seem either sceptical of science-based archaeology or baffled by its results. The underpinnings of science-based archaeology may conflict with social or behavioural factors unsuited to quantification and grouping procedures. Thus, the interaction between archaeologists and their science-based colleagues has been less profitable than it might have been. The main point I consider in this study, and exemplify by considering metals provenance studies in the Bronze Age Mediterranean, is the relevance and application of the stated aims of science-based archaeology to the contemporary discipline of archaeology. Whereas most practitioners today recognise that science-based archaeology has the potential to contribute positively to the resolution of problems stemming from our field's inadequate and incomplete data resource, I contend that science and scientific analyses alone cannot adjudicate between cultural possibilities. Rather they provide analytical data which are likely to be openended, subject to multiple social interpretations, and in need of evaluation by collaborating archaeologists using social theory.
\end{abstract}

Biographical Note: A. Bernard Knapp is Professor of Mediterranean Archaeology in the Department of Archaeology, University of Glasgow. He received his $\mathrm{PhD}$ in Mediterranean Archaeology from the University of California, Berkeley, in 1979. He has held research appointments at the University of Sydney, the Cyprus American Archaeological Research Institute, Cambridge University (England), and Macquarie University (Sydney). Current research interests within and beyond the Mediterranean include social theory, archaeological survey, the archaeology of mining, and gender in archaeology. He co-edits the Journal of Mediterranean Archaeology (with John F. Cherry) and edits the series Monographs in Mediterranean Archaeology. 
Many, if not most, archaeologists regard archaeometry as a sometimes interesting, largely irrelevant, and definitely optional endeavor. (Dunnell 1993: 161)

It is becoming clear that the interpretation of lead isotope data has not taken place within a framework which reflects the true complexity either of ore deposits, or - perhaps more importantly - of metal supply and circulation in the ancient world. We contend that this crisis of confidence stems, not from lead isotope measurements themselves, but from their interpretation. (Budd et al. 1996: 169)

\section{Introduction}

Philosopher of science Stephen Toulmin (1977: 157-58) once pondered whether there was an 'alternation ... between periods in which the focus of scientific inquiry is on the development and refinement of general intellectual techniques for their own sake, ... and periods in which the focus shifts from such general techniques to particular kinds of concrete problems and problem situations.' In other words, are there times when scientific outlook and practice tend to be more theory-driven, and other times when they tend to be more empirical and method-driven? Any viable intellectual discipline may choose either to explore the implications and uses of a given set of techniques and procedures, or to look for ways of improving them. By the same token, interdisciplinary research may choose to foster the autonomy of individual fields whilst refining their own general procedures, or else they may opt to find ways of drawing on pooled resources to resolve concrete problems and applications. With specific reference to the interdisciplinary field of science-based archaeology, one primary aim should be to draw upon pooled resources in the attempt to resolve specific archaeological, cultural or historical problems, if not modern-day social issues. Indeed, that goal has been touted over the years by a diverse group of archaeologists, scientists and archaeological scientists (most recently, Demirici et al. 1996; McGovern 1995; Renfrew 1992; Vaughan 1995; Young et al. 1999).

In a recent issue of Antiquity, Killick and Young (1997) explored ways of promoting a more effective interaction between scientists and archaeologists. They concluded that, whilst it is possible to conduct viable scientific research in archaeology, it remains difficult to maintain continuity within the field or to educate the future consumers and practitioners of science-based archaeology without formal academic training. Of course, this problem is less acute in Britain where, as those authors realise, the academic and institutional integration of archaeology and science-based archaeology has been under way for some time. Serious debate over integrating science within archaeology began with a 1981 'round table' discussion entitled Future

Directions in Archaeometry (Olin 1982). At the conference, the archaeological intuition was that most science-based research served no demonstrable purpose. For their part, the scientists were clearly frustrated with archaeological ignorance of the methods, potential and limits of sciencebased archaeology (Killick and Young 1997:518). Today, almost twenty years along, archaeologists and their science-oriented colleagues are still bogged down in this controversy.

Recently, Robert Dunnell (1993) entitled a review article 'Why archaeologists don't care about archaeometry.' Rick Jones (1988: 1) suggests that science-based archaeology is a 'second class 
science.' And Christopher Chippindale (1994:5-6), writing in a recent editorial for Antiquity, complains that:

The claim [of archaeological science] to high status ... rests on its giving a more secure knowledge, to be measured by the certainty of scientific understanding, and to be displayed to the rest of us by a fetish for exact measurements, not always of qualities or entities that have a well-defined and relevant existence. So it is curious that the disputations among archaeological scientists seem deeper and more intractable than the ones in the less 'objective' end of the business, and even slower to be ended by indisputable facts.

Referring to a series of papers that appeared in Archaeometry 34 and 35 (1992, 1993), Chippindale levelled a pointed attack on lead isotopic analyses (LIA) of Mediterranean metals from the Bronze Age, quoting the research team from Oxford (Nöel Gale and Zophia Stos-Gale) who seemed to be challenging their scientific colleagues to become more understanding and more understandable. Chippindale emphasized the equivocal nature of conclusions based on LIA, with respect to an ore body's isotopic signature, smelting techniques and mixing of ores, wastes and slags and even the analytical and statistical techniques employed. Moreover, re-measurement and/or rejection of old analyses in new compilations of lead isotope data have shown that not all measurements were of the highest precision (Budd et al. 1996:169). Indeed John Cherry and I have repeatedly pointed out the same problems (Cherry and Knapp 1991; Knapp and Cherry 1994:32-40).

Many archaeologists remain sceptical of science-based archaeology or baffled by its results. Sarah Vaughan (1995) argues that the scientific underpinnings of science-based archaeology often conflict not just with the nature of the materials studied but also with a whole array of behavioural factors that are not amenable to quantification and grouping procedures. In her call for more humanistic input into science-based archaeology, Vaughan stands completely at odds with Dunnell's (1993:163-4) appeal for a real scientific archaeology: 'The effort, rigor, and cost of physical analyses are lost in a humanistic approach where they serve only to inspire storytelling — stories that are not testable in any scientific sense.' However, Dunnell's view of 'archaeology as science' has little to do with the concerns of science-based archaeology but rather hearkens back to a positivist archaeology driven by a belief in a (biological) evolutionary 'science' (Dunnell 1992:86-90).

Is it really the case, then, that the level of interaction between these two camps has changed very little? Who, if anyone, is right or wrong in this volley of charges and counter-charges between science and archaeology? The main point I wish to consider in this study, and exemplify by considering metals provenance studies, is the relevance and application of the stated aims of science-based archaeology to the discipline of archaeology. In so doing, I also consider some of the reasons why science and archaeology, especially in the Mediterranean, have not been as well integrated - in interdisciplinary terms - as they might have been. In order to consider the various complaints that have been aired, I discuss the most recent research in archaeometallurgy and the Mediterranean metals trade, the latter the same topic targeted by Chippindale and one in which I have been involved professionally on several levels over the past decade. Whereas most practitioners today recognise that science-based archaeology has the potential to contribute positively to the resolution of problems stemming from our field's inadequate and incomplete 
Knapp-Archaeology and Science/EJA

data resource, I contend that science and scientific analyses alone cannot adjudicate between cultural possibilities. Rather, they provide analytical data which are likely to be open-ended, subject to multiple social interpretations, and in need of evaluation by collaborating archaeologists using social theory. I begin with a brief consideration of the historical context within archaeology that helped to foster scepticism and acrimony instead of collaboration and co-operation.

\section{Processual Archaeology and Archaeological Science}

When 'new archaeologists' like Lewis Binford and David Clarke broke ranks with the culturehistorical regime in archaeology, they were not much interested in events or in individuals but they were interested in society. As part of a positivist movement in archaeology, they examined the long-term ecological and environmental processes which, they believed, enabled or constrained certain kinds of cultural and social development. Binford called for an entirely revamped archaeological research strategy, essentially an anthropological 'science' based on a formalised, statistical methodology where hypothesis testing would hold central place. David Clarke, on the other hand, still adhered to Childe's notion of an archaeological culture, and placed more emphasis on both historical evidence and geography than did Binford. Nonetheless, both Clarke and Binford emphasized quantitative, scientific perspectives in archaeology and used 'systems theory' as an important means of explaining cultural change. Much of mainstream archaeology, especially in America, became a 'hypothetico-deductive' pursuit, seeking general laws of human behaviour. This positivist approach emphasized orderly data collection and analysis within a sound theoretical framework geared to explain the past through generalisation. Combined with the locational techniques and statistical analyses that helped to establish a quantitative revolution in spatial archaeology and the 'new geography' alike, processualism still holds a prominent place in archaeology's internecine battles.

Science-based archaeology (archaeometry) developed into a highly respected sub-discipline of the new archaeology, using approaches such as radiocarbon dating, dendrochronological calibration, phytolith analyses, palaeoethnobotany, palaeopathology, provenance studies, and many more. Research interest in all of these areas stemmed directly from a processual, positivist focus on 'science.' Many anthropological archaeologists in the USA still argue that archaeology is and must remain a scientific endeavour; and they mean hard science - not social science.

Since the limitations of such 'forensic archaeology' have been pointed out repeatedly, there is no reason to dwell upon them here. Archaeology in the 1990s has moved well beyond processualism's narrow, systemic approach, its view of itself as an 'anthropological' science of the past, and its promotion of Science with a capital 'S.' It seems fair to say that most archaeologists working at the beginning of the new millennium seek to move beyond polemics and to explore areas of possible agreement amongst contemporary archaeologies (e.g., Hodder 1991; Lightfoot 1995; Preucel 1991; 1995; Schiffer 1996; Shanks and Hodder 1995; Shanks and McGuire 1996; Trigger 1991). Multiple paths and perspectives are inevitable, and a postprocessual or interpretative approach dictates that archaeologists must learn to live with the notion of mutually irreconcilable views about the past (Knapp 1996:150-2). Archaeologists of 
Knapp-Archaeology and Science/EJA

all persuasions should be encouraged to develop a body of theory that will help to link data collection and scientific analysis with social inference.

Thus, we may expect a plurality of interpretations as we seek out common ground amongst different archaeologies. Archaeological goals cannot be met by empirical means alone - that is, by limiting oneself to the exclusive or narrowly scientific analysis of material data. The division of knowledge into 'facts' and 'theories' is a spurious undertaking, and 'truth' or 'reality' is relative at best. Archaeological evidence, furthermore, is at least partially defined by archaeological assumptions about what is or is not relevant: archaeological data are thus partly constituted by theory, implicitly or explicitly. If field techniques and analytical methods developed in archaeology and science-based archaeology are fundamental to the study of the past, so too is an understanding of social theory, which requires as much effort and rigour as do the more empirical aspects of archaeological or scientific investigation. What we observe today as archaeologists are the remnants of past human actions. In the absence of theory that focuses on the workings of society, it is impossible even to consider what sort of phenomena gave rise to these materials, their distribution or structuring. Theory, in turn, can provide the wherewithal to understand past social realities, which is the ultimate archaeological knowledge we seek. If science-based archaeology is to contribute to such knowledge, then scientific data need to be 'read' with a view to increased understanding of past societies. Let us consider whether this is possible by looking more closely at metals provenance studies, in particular at the most recent work in sourcing copper ores and oxhide ingots in the Bronze Age Mediterranean.

\section{Science and Archaeology: Provenance Studies}

It is one of the sadder aspects of this [science and archaeology] partnership that irrefutable authority through 'scientific objectivity' has been perceived by archaeologists [as...] the prize attained at the price of intellectual independence. (Vaughan 1995:264)

We believe ... that more realistic archaeological interpretations of the analytical data are required; a more detailed examination of archaeological lead isotope methodology and the deconstruction of aspects of the current framework are essential to this. (Budd et al. 1996:169)

In reconstructing prehistoric trade or production systems, archaeologists have employed several provenance techniques; amongst the most common are neutron activation analysis (NAA) and lead isotope analysis (LIA). The main aim of provenance work is to identify 'objectively' and to distinguish between local and foreign materials, and/or to eliminate from consideration individual sources of stone, metal or clay. Analytical work, in principle, should be able to distinguish between distinct sources of raw material, and compositional variation should be greater between than within sources. However precise the results of such work appear to be, they are unlikely to make a meaningful contribution to the understanding of social processes such as production, distribution or consumption without theoretical reflection. And yet critical examination of the links between archaeological data, analytical results and behavioural interpretation has been rare, especially given the amount of provenance work carried out on metals, ores, pottery, coins and other materials (e.g., in the Mediterranean, see Gale et al. 1997; Jones 1986; Knapp and Cherry 1994; Pernicka 1987; Seeliger et al. 1985). Since the relationship between chemical elements or 
Knapp-Archaeology and Science/EJA

isotopic ratios and human behaviour is highly complex, the ability to define and discriminate amongst physical data is not directly relevant to social interpretation: the association between analytical variables expresses relationship, not necessarily cause. In addition, more is not necessarily better: by increasing the number and variety of variables in statistical analysis, the amount of irrelevant measures also increase (Read 1989:166-7). Since there are only three independent variables in lead isotope studies, the usefulness of multivariate or discriminant function analyses is strictly limited (Budd et al. 1996:169-70; Scaife et al. 1996).

Because the retrieval, classification and interpretation of archaeological data can be so complex, quantitative methods should always be used in conjunction with traditional archaeological strengths (pattern recognition) and limitations (the nature of causality) (Kintigh 1987:131-33). The technical complexity of the physical and biological sciences is such that non-specialists often cannot determine either methodological consistency or the applicability of analytical results to theoretical or social issues (Trigger 1988:5). In the end, however, no matter how complex the methods, techniques and analytical output of the physical and biological sciences may be, archaeologists alone bear the ultimate responsibility for integrating scientific results into culturally meaningful interpretations. When it comes to assessing quantitative data and statistical output, scientists and archaeologists must engage in a reciprocal dialogue. Bland technical data only become culturally meaningful when they are integrated and interpreted within the relevant archaeological, historical, technological or social context (Barnes et al. 1988:297; Dobres and Hoffman 1994; Vaughan 1995:269-70). As stressed hitherto (e.g., Knapp and Cherry 1994:8-10), this level of collaboration has yet to be achieved with provenance work in the Mediterranean (for a productive Mesoamerican counter-example, see Hosler and Macfarlane 1996). Some people use inappropriate techniques, others use one technique to the exclusion of others, whilst still others fail to consider the analytical results of archaeological data within a social context. Moreover, open access to scientific data has not been a hallmark of Mediterranean provenance studies (Budd et al. 1996:173). Long ago, Mark Pollard (1983) outlined some of the limitations of analytical or statistical techniques used in isolation; his more recent overviews of science-based archaeology (1992: 1995) indicate that little has changed, despite his own relentless efforts to ensure that they would.

\section{The Sources of Mediterranean Metals, Ores and Oxhide Ingots}

Archaeologists working in the Mediterranean have tended to be either agnostic about, or uncritically receptive of, the tentative and often contradictory results emerging from scientific analyses. Both stances are extreme. Knapp and Cherry (1994:33-4) emphasized that, whereas provenance data can provide powerful analytical tools to archaeology, they also raise multiple questions that cannot be answered unequivocally. For example, how consistent are the Mediterranean provenance data generated over the past two decades (a question of precision)? Under what conditions are the various techniques in common use actually reliable and with what limits of inference (a question of accuracy)? Can we really compare all these analytical data, and, if so, how does one assess the degree of comparability? The relevance of particular analytical and statistical approaches for constructing interpretative models of production and 
Knapp-Archaeology and Science/EJA

distribution within the Bronze Age Mediterranean is not something that can be accepted on faith, pursued blindly or given an aura of infallibility. However, through a combination of analytical study and archaeological feedback - viz. a more properly constituted archaeological science - the possibility of understanding social or economic interactions in the Bronze Age Mediterranean would be greatly enhanced.

Muhly (1977:77-78) once expressed great scepticism about provenance studies for metals, concluding that before anything could be said about the copper trade in the Mediterranean Bronze Age, it was necessary first to understand the basic technology of Bronze Age copper metallurgy. This task, he argued, could best be accomplished through detailed analytical studies of copper 'oxhide' ingots. At the time, it was widely presumed that these ingots represented a primary raw material, untainted by remelting or alloying, the very form in which raw copper was shipped from source to production centre during the Late Bronze Age. 'We must ... learn all we can about these ingots: how they were made, why they were made and where they were made' (Muhly 1977:81).

Given the deluge of analytical, statistical and interpretative studies carried out on ingots and the Bronze Age metals trade since that time, Muhly's dictate appears to have been taken very seriously. At first, analytical work on metal composition sought to distinguish quantitatively and semi-quantitatively between copper, copper alloys and tin-bronzes; to differentiate between native and smelted copper; and to determine whether and where sulphide, as opposed to oxide, ores were smelted (Balthazar 1990:32). Atomic Absorption Spectrometry, Instrumental Neutron Activation Analysis and Proton Induced X/Gamma-Ray Emissions were all employed in the attempt to establish or refine provenance (e.g., Lo Schiavo et al. 1990; Maddin 1988; Muhly et al. 1988; Pernicka 1987). The spotlight, however, increasingly fell on LIA, and on analytical work carried out in Oxford, Heidelberg and Washington.

In principle, the isotopic abundance of lead within lead-rich mineral deposits (especially sulphide and oxide ores) can distinguish between deposits and so may help to establish the provenance of ores or artifacts derived from metallurgical processing. More importantly in terms of methodology, LIA can exclude - unequivocally — certain ores or ore bodies as sources of metal artifacts or ingots. Even where lead concentrations in samples are low, accuracy of measurement is not affected, as long as contamination of any sort is avoided (Farquhar and Vitali 1989:39; Gale 1989a:471-78). However, there still remain several unresolved problems with the use of LIA in metals provenance work:

1) different ore deposits may contain lead that is isotopically indistinguishable - a factor that makes it impossible to assign an artifact or ingot positively to a specific ore source (Pernicka et al. 1990:278; Reedy and Reedy 1988:66-7);

2) not all ore sources are known, and the isotopic variation within each is also therefore unknown (Killick 1992:120-21); 
Knapp-Archaeology and Science/EJA

3) other materials used in smelting copper (i.e., fuels and fluxes) or alloyed with it (e.g., tin) may contain lead unrelated to that derived from the copper ore (personal communication, Paul Budd);

4) because human beings were always involved in the extraction of ores and the production and trade of metals and because economic constraints on availability always obtained, it is possible and indeed likely that more than one ore source would have been involved at the manufacturing or refining stage, a factor further compounded by the likely melting and re-use of bronze which may contain lead from several different ore sources (Muhly 1985a; Needham et al. 1989:383-85; Budd et al. 1995). Mixing ores from different deposits will provide a lead isotopic ratio that may bear no relationship to an actual ore-body (Killick 1992:120-1);

5) finally, it must be pointed out that very few copper or bronze metal artifacts analysed have an isotopic signature which can be correlated with the field established for the copper oxhide ingots (Muhly 1998).

Barnes et al. (1986:2) argued forcefully that '... [metal] objects from the eastern Mediterranean are notoriously difficult to classify because of complications arising from the mixing and overlapping effects.' If that is the case, one must wonder why another team from the Smithsonian (including Barnes, albeit posthumously) saw fit, on the basis of statistical manipulation (discriminant function analysis - DFA), to assign artifacts to specific sources (Sayre et al. 1992). DFA or indeed any sophisticated multivariate treatments are now regarded as inappropriate or unnecessary for assessing data generated by lead isotope analysis (Scaife $e t$ al. 1996). Moreover, recent work by Baxter and Gale (1998) unambiguously demonstrates that points within lead isotpoic 'fields' are not necessarily normally distributed. When the Oxford team initiated LIA as a provenance technique for the study of Mediterranean metals, they maintained that the only conclusive evidence LIA could provide was negative - i.e., establishing that an artefact or ingot could not have come from a particular source (Gale and Stos Gale 1982a, 1982b). Their subsequent work has not infrequently overlooked this principle, a factor that was instrumental in eliciting Chippindale's exasperation, or provoking the Bradford group's various responses. Here is a clear case in point where science-based archaeologists have been inconsistent and internally contentious, which has had the effect of compromising the relevance of scientific applications to archaeological enquiry.

\section{Oxhide Ingots: Sourcing, Pooling and Recycling}

The gap between scientific results and archaeological understanding is nowhere better exemplified than in the attempts to interpret lead isotope and trace element analyses carried out over the past decade on copper oxhide ingots found throughout the Mediterranean but concentrated on the islands of Cyprus, Crete and Sardinia (Gale 1989b: 1991b; Lo Schiavo et al. 1990; Muhly et al. 1988; Stos-Gale et al. 1997). Budd et al. (1995) have recounted in some detail the sequence of developments over the past fifteen years. The crux of the problem (and perhaps a key to its resolution?) is that virtually all of the oxhide ingots analysed form a tight 
Knapp-Archaeology and Science/EJA

cluster on lead isotope plots, within or near the 'field' established for Cyprus, and at least distinct from the 'fields' established for locally-produced Sardinian artifacts and for some individual Sardinian ore deposits. It is also worth noting that there appear to be no ingots made of copper from Laurion in Greece - one of the main 'sources' identified for many of the metal artifacts analysed by LIA (Muhly 1998:29). Gale and Stos-Gale (1987) long ago concluded that the ingots found on Sardinia were made from Cypriot copper, and they have never retreated from that position (Gale 1989b: 1991b; Gale and Stos-Gale 1995; Stos-Gale et al. 1997:115). As we shall see, such a conclusion either needs careful qualification or may be entirely erroneous. LIA has also assigned a Cypriot origin to some of the oxhide ingots from the Cape Gelidonya and Uluburun shipwreck deposits (Gale 1991b; Pulak 1995:47; 1997:237-8; cf. Maddin 1989; Muhly 1991), whereas the ingots found on Crete indicate diverse and unknown origins (Knapp and Cherry 1991:191-3; Muhly et al. 1988:290-1), thus exemplifying one of the unresolved problems in using LIA.

The tight clusters of LIA data for the copper oxhide ingots could be the result of producing copper from a single source - depending on the geochemistry of the deposit, anything from a single gallery within a mine to a whole ore field - or by recycling and metal mixing.

Unfortunately, LIA cannot help in any way to distinguish between the two. Such a judgement is purely subjective and should be informed by independent archaeological data. Accordingly, it is possible to suggest three alternative interpretations of the currently published data regarding the production of oxhide ingots:

1) single source: ingots were produced from copper metal extracted from ores having a single source (using fluxes, etc. also consistent with that lead-isotope signature), perhaps refined and then cast and distributed;

2) multiple sources: ingots were produced from ores derived from different localities which made roughly consistent contributions to a 'pool' of copper. Production would have involved the gathering of plano-convex, bun or other ingots from various smelters to a central place(s) for re-melting or refining into oxhide ingots;

3) recycling: as interpretation (2) but also involving the inclusion of scrap metal and recycled artifacts into the pool prior to refining.

In a re-examination of much of the relevant published data on ores, ingots and artifacts, Budd et al. (1995) suggested that the Mediterranean region contains so many copper deposits of similar geological age, and/or derived from isotopically similar fluid resources, that it is impossible to attain the resolution needed to ascribe or clearly refute a Cypriot, Sardinian or any other origin. Whatever the merits of employing trace element data on gold/silver ratios as a supplementary metals provenance technique (Gale and Stos-Gale 1995:39), they cannot verify a Cypriot source for the Sardinian ingots. The lead isotopic data measurements used to establish individual source fields that form the basis for making assignments or distinctions have not been consistently precise. The consequent shifting and modification of the lead isotope fields have not helped to inspire archaeological confidence (Budd et al. 1996:169-71). Two Cypriot fields are noted in 
Sayre et al. (1992: 1995:46); the five Cypriot fields proposed in Gale and Stos-Gale (1992: 1995:36-37) were later reduced to one (Stos-Gale and Gale 1994; Stos-Gale et al. 1997).

However one regards these developments, the rather dramatic changes in analytical interpretation have had a profound effect on the conclusions that may be drawn from LIA of ores, artifacts and ingots. Most significantly, the modified source fields indicate that the lead isotope compositions of several oxhide ingots from Sardinia, the Anatolian shipwrecks, Crete and even Cyprus are inconsistent with the Cypriot field (Budd et al. 1995:11-13, figs 3-4). Moreover, the Cypriot field as presently defined certainly does not fully express the extent of variation within the island's ore deposits. The much greater variation in lead isotope ratios for Sardinian ores, which completely swamps any signal emitted by the Cypriot field (Budd et al. 1995:16, fig. 5), the uncertainty over which deposits were actually exploited during the Bronze Age, and the still limited, if increasing, number of ore samples currently available from mines on Cyprus and Sardinia (e.g., Gale et al. 1997; Lo Schiavo et al.1990), make it unsound both in principle and in practice to maintain that one island, or worse one deposit on one island (Stos-Gale et al. 1997), provided the raw material that went into producing most of the copper oxhide ingots found in the Mediterranean.

What sort of cultural interpretations have archaeological scientists given to the lead isotopic and elemental data on copper oxhide ingots, and to what extent has archaeological opinion influenced their interpretations?

\section{Sourcing (interpretation 1)}

On the basis of a new suite of lead isotope data, Stos-Gale et al. (1997) have argued for the predominance of the Skouriotissa region and, in particular, the primacy of Apliki Karamallos, in the production of all copper oxhide ingots that appear, analytically, to be consistent with production from Cypriot ores. Such a claim is unprecedented and, whilst coherent in analytical terms, seems quite at odds with other recent analytical interpretations. Sayre et al. (1995:50), for example, argue for '... at least five isotopically different groups of oxhide ingots which probably came from different sources.' Furthermore, this recent claim by the Oxford team is inconsistent with a suite of spatial, social, historical and economic interpretations of the archaeological record (amongst others, see Muhly 1991; Keswani 1993; Keswani and Knapp 1997; Knapp 1997). The notion that a single ore source could have been so prominent in a system characterised by the long-distance transport of both luxury goods and accumulated bulk commodities seems more akin to modern industries with their specialised work forces and dedicated technologies than to prehistoric social realities (Budd et al. 1996:172). Such views have been criticised from multiple perspectives (e.g., A. Sherratt 1994:337-38; Budd and Taylor 1995; Muhly 1998:29; various papers in Knapp, Pigott and Herbert 1998). At the same time, the notion of a single source area and the prominence of a single site contradicts previous interpretations by the Oxford team, which argued for the exploitation of multiple ore deposits round the Troodos (e.g., Gale and Stos-Gale 1992; Stos-Gale and Gale 1994:106). 
If a large proportion of Bronze Age primary smelting activity was carried out at one site, how can we understand smelting sites like Politiko Phorades, which once would have been ubiquitous throughout the pillow lavas that encircle the Troodos Mountains (Knapp, Donnelly and Kassianidou 1998; Knapp et al. 1999) ? Although most such sites have now been destroyed or obscured by twentieth-century mining, we know from reports of early 20th-century prospectors that the remnants of ancient industrial activities were used to target potential ore deposits (Lavender 1962). Moreover, we can now corroborate such reports with ancient evidence found in modern spoil heaps like Agrokipia Kriadhis and Mitsero Kokkinoyia (Kassianidou and Wright 1996). Modern-day mining, moreover, has obliterated the Late Bronze Age site of Apliki Karamallos and its surrounds, so that the proposal promulgated by the Oxford team on the basis of their analytical data can in no way be reassessed on the ground, although current research on the Apliki material held in the Cyprus Museum may one day provide further insight (Muhly 1989:306-10).

As an archaeological counterpoint to the model offered by the Oxford group, our preliminary reconstruction of the industrial landscape around Politiko Phorades indicates that the ores used at this Late Bronze Age smelting site came from mines on the gossan ridge about 800 metres North-West of the site, whilst the ore beneficiation and roasting would have been carried out nearby, on that same ridge. Geobotanical and geomorphological fieldwork carried out as part of the Sydney Cyprus Survey Project (SCSP: Given et al. 1999) reveals a dramatically different landscape around Phorades, suggestive of a microregional settlement pattern with specialised production units represented by several sites and installations (personal communication, Sven van Lokeren). In other words, what we see is a self-contained metallurgical area with all the essential raw materials, social organisation and communications necessary for small-scale, localised production that would have been integrated into the much broader economic and ideological system of the Late Bronze Age (Keswani 1993; Keswani and Knapp 1997; Webb and Frankel 1994). Given the results of this new, still largely unpublished material from Phorades and from the SCSP more generally (Given et al. 1999; Knapp, Donnelly and Kassianidou 1998; Knapp et al. 1999), the suggestion that Apliki was the source of all the copper used in Mediterranean oxhide ingots seems untenable.

\section{Pooling (interpretation 2)}

Both the Heidelberg and Bradford groups have shown that recognition of the limitations of LIA need not impede its application to archaeological problems (e.g, Begemann et al. 1989; Budd et al. 1993: 1995: 1996:169; Pernicka 1995; Pernicka et al. 1990). Access to the relevant data measured with an acceptable level of precision can facilitate alternative cultural interpretations - one of the most significant contributions that science-based archaeology has to offer.

As indicated earlier, Mediterranean copper oxhide ingots have remarkably consistent lead isotopic abundance ratios: fifty ingots from Cyprus, Sardinia, the Aegean, the Levant, and the Cape Gelidonya/Uluburun shipwrecks indicate a spread of only $0.5 \%$ on a conventional plot of 
Knapp-Archaeology and Science/EJA

the data (Budd et al. 1995:13-15, and fig. 5; Gale 1989b:257, fig. 29.18). Most archaeologists and scientists involved have interpreted this as indicating for these ingots a common Cypriot origin but from multiple ore sources; this would be equivalent to a process of 'pooling' ore sources. In the production process, primary smelting of raw copper ores would have produced matte; secondary smelting would have produced 'black copper' (rich in iron) which would then have been refined and cast into ingots. If the last step in this process took place in Cyprus's coastal centres, then we can suggest that black copper - in the form of bun (or slab, or planoconcave) ingots - from different mines or smelting workshops were pooled to produce the more pure, copper oxhide ingots (personal communication, Vasiliki Kassianidou).

Extrapolation from the results of the analysis of the oxhide ingots from Cape Gelidonya and Uluburun (Gale 1991b:227-31; Pulak 1995:47) to all the ingots recovered from these two wreck deposits (Bass et al. 1989; Pulak 1997:237-8) produces a total of about 380 ingots - ten tons of metal - consistent with production from Cypriot ores. However, the combined weight of archaeological and compositional evidence also suggests an alternative view - recycling (Budd et al. 1995; Muhly 1991). The position of the ingot samples vis-a-vis the measured ore source fields of the Mediterranean is somewhat anomalous even for Cyprus (Muhly and Stech 1990). Either something is amiss with assuming bivariate normality of the existing Cypriot ore-source field (cf. Baxter \& Gale 1998) or else some unknown or unconsidered manufacturing process has caused a shift in the isotopic composition of the ingots.

\section{Recycling (interpretation 3)}

Budd et al. (1995) maintain that no exact match will ever be found, because the recycling of metals and the re-use of scrap metal or other alloys had become commonplace by the Late Bronze Age, as a result of the intensified economic activity that characterised this international era and created the demand for high-value bulk items like copper oxhide ingots in the first place (Knapp et al. 1988; Muhly 1985b; S. Sherratt 1999:175-77; A. Sherratt and E.S. Sherratt 1991; Stech 1982). In fact, the international trade of bulk copper in the form of standardised ingots must also represent a growing commodification of metals, a process in which the original sources of metal increasingly became irrelevant, where the motivating force is to maintain, if not expand, the already vast scale of the inter-regional trade in metals and in which there is every economic and ideological incentive to use mixed sources of copper ores, or even recycled metals, in the production of copper oxhide ingots.

The analytical results at least allow one to question the assumption that all the primary smelting copper which went into any single oxhide ingot derived from a single source. In a series of comments to Budd et al.'s (1995) proposal of a widespread use of recycled metals (Gale and Stos-Gale 1995; Hall 1995; Sayre et al. 1995; Muhly 1995; Pernicka 1995), there was general agreement that ores from more than one source (i.e., 'pooling') could have been used in the primary smelting of copper ingots, but it was vigorously disputed whether any recycled artifacts were ever incorporated into those ingots. In other words, one must distinguish between the recycling of alloyed bronze artifacts into copper oxhide ingots, if such a practice was ever 
Knapp-Archaeology and Science/EJA

followed, and direct recycling into new bronze artifacts. Recycling into oxhide ingots would have involved a refining process that at least attempted to remove tin, arsenic or other alloying elements (Muhly 1985a); recycling directly into new bronze artifacts required no refining.

If continued recycling of copper or bronze, as well as entrained lead, from various sources took place as Budd et al. (1995) have argued, the clustering of the abundance ratios of the resulting ingot products would actually become tighter (as is the case), and the overall lead isotope signature would become modified to the extent of reflecting the overall, Mediterranean-wide input into the recycling system, rather than any specific source. In other words, if a widespread system of recycling metals was operating within the Mediterranean Late Bronze Age and if this practice also operated in the case of the copper oxhide ingots, the position of these ingots on a lead isotope ratio diagram would reflect the isotopic composition of the trading network overall instead of any one of its constituent parts. Whilst this view remains contentious, the wider archaeological record does not permit us simply to reject it out of hand. It must be made clear, however, that the same result — the clustering of the oxhide ingots on LIA plots - would occur if raw copper from multiple sources were pooled in their production.

Whereas evidence for recycling metal goods into new artifacts is plentiful and steadily increasing, the recycling of refined bronze or of unalloyed copper into copper oxhide ingots remains at best a theoretical possibility, substantiated in part by the frequent occurrence of oxhide ingot fragments in the numerous hoards found throughout the Aegean and Cyprus at this time (Knapp et al. 1988). Brief examples from Sardinia and Cyprus nonetheless make a clear case for the general phenomenon of recycling metals during the final stages of the Late Bronze Age in the Mediterranean.

$\underline{\text { Sardinia }}^{1}$ Evidence for recycling metals, in the form of hoards comprising scrap metal and broken artifacts, bun ingots and oxhide ingots, is found throughout Sardinia. Twenty-six sites widely distributed on the island, most of which are argued to date to the Final Bronze Age or Early Iron Age, contain oxhide ingots or ingot fragments (Lo Schiavo 1998:99-100, 110). The oxhide ingots that have been analysed are generally of more pure copper content than the local bun (or 'plano-convex') ingots (Tylecote et al. 1984:129), which often contain significant percentages (30-50\%) of iron or lead, or even tin (about 10\%) which in effect makes them bronze ingots The possibility of using lead- or iron-rich bun ingots in the production of oxhide ingots has at least been mooted (Lo Schiavo et al. 1987:182-84). The analysed artifacts from some Sardinian hoards contain notable levels of iron and lead, and could have been produced from bun ingots if the latter had been mixed with a more pure source of copper, such as oxhide ingots. Examples from two Nuragic complexes shed light directly on the practice of recycling.

Near the village of Ossi (Sassari) is the Nuragic village of Sa Mandra 'e Sa Giua, where the discovery of an unusual founder's hoard containing objects partially fused together offers the possibility of seeing which metals a smith regarded as suitable for producing remelted (i.e., recycled) metal (Lo Schiavo 1981:fig.298). Of course, one might consider that these materials 
Knapp-Archaeology and Science/EJA

were fused together in a taphonomic, rather than a pyrotechnological, process but there is no way to check that possibility at this stage. The partly melted mass of metal included fragments of both oxhide and bun ingots as well as broken tools. Subsequent elemental analyses of one oxhide ingot and eight bun ingots showed that seven samples, including the oxhide ingot with $1 \%$ iron and $1.2 \%$ arsenic, contained amounts of iron (up to $10.68 \%$ in one) that would have produced embrittled objects (Lo Schiavo et al. 1987:180). At the Nuragic complex of Sa Sedda 'e sos Carros, near the village of Oliena in Nuoro, the presence of scrap copper, bronze, lead and iron prompted the excavator to suggest that the site functioned as a recycling centre, although six bun ingots found at the site might imply that recycling was not the only source of metal (Lo Schiavo 1989:36). Once again compositional analyses have shown that the bun ingots contain inordinately high levels of iron and lead (up to 50\%) (Lo Schiavo et al. 1987:181-82). Other ingots have tin contents ranging from $3-10 \%$, but it remains uncertain if these were deliberately cast as bronze ingots, or if they were perhaps prepared from bronze scrap mixed with refined oxhide ingots.

I leave aside here the issue of the comparative origin(s) of oxhide ingots found on Sardinia and Cyprus, noting only that the consistent quantity of arsenic present in the Sardinian ingots (from $0.16 \%$ to $0.54 \%$ ), and the absence of arsenic but more erratic presence of iron in the Cypriot ingots (Lo Schiavo et al. 1987:182-83), are consistent with separate origins. Tylecote (Balmuth and Tylecote 1976:201) also argued for different sources for the ores used in Sardinian and Cypriot ingots, whereas LIA indicates that the analysed oxhide ingots from Sardinia are consistent with production from Cypriot copper ores (Gale 1989b:258-262; above, pp. xx-xx). The main point I wish to make is that a long-standing focus on Sardinian archaeometallurgy, including additional data beyond that cited here for hoards with large numbers of oxhide ingots associated with scrap metal (Lo Schiavo 1998), provides indisputable evidence for the recycling of metals derived from re-melted bronze artifacts, bun ingots and oxhide ingots.

\section{Cyprus}

The existence of metal hoards, copper smelting or remelting workshops, and an exceptionally diverse range of materials for metallurgical enterprise on Bronze Age Cyprus is well known and widely published (e.g. Muhly et al. 1982; Muhly 1989; Knapp 1986: 1988; Knapp et al. 1988). However, it is worth reiterating that, given the quality and quantity of material recovered in most 'foundry' hoards, the storage and use of scrap metal should be regarded as indicative of a flourishing metal-producing industry, not one in the throes of decline. These hoards represent material collected together for their value as metal for recycling, not for the intrinsic value of the original product (Knapp et al. 1988:237, 257-58). Or, as S. Sherratt (1998:299) recently put it, by the end of the 13th century BC, there may have been a much greater emphasis in Cyprus on manufacturing rather than producing copper for export, in which case the 'international' value of Cypriot copper (and oxhide ingots) would have been less crucial to the island's economy, and any source of metal would have been adequate. 
Knapp-Archaeology and Science/EJA

A recent study that calls into question the function of certain workshops at Kition as primary smelters at the same time offers an impressive array of archaeological and archaeometallurgical evidence for the sheer scale of recycling that was conducted on Cyprus during the 13th-12th centuries BC (Karageorghis and Kassianidou 1999). ${ }^{2}$ Moreover, these authors suggest that the presence of large quantities of bone ash in Kition's Northern Workshops may reflect its use as a de-oxidising agent in the production of oxhide ingots and bronze objects (Karageorghis and Kassianidou 1999:180-83). With regard to recycling, Karageorghis and Kassianidou cite evidence from Cyprus in the form of scrap metal (Kition, Enkomi, Ayios Dhimitrios) and founder's hoards (especially those found at Enkomi, Kition, Mathiati and Pyla), and from the Aegean in the form of the Pylos JN series of Linear B tablets, which refer both to recycled bronzes and perhaps to fractions of whole copper oxhide ingots or even bronze ingots (see Smith 1992-93:182-83, 193-94, 198; Zaccagnini 1986:415-18). In Cyprus, Building XI at Kalavasos Ayios Dhimitrios, with its associated array of crucible or furnace fragments, scrap metal and oxhide ingot fragments, provides further contextual evidence for recycling (South 1989:320). Bronze scraps, including pieces of open-work bronze stands, have been recovered not only at Enkomi, Kition and Pyla but also at the more or less contemporary Late Bronze Age II site of Tel Nami in Israel (Artzy 1994:126-29); were these too selected for re-melting, perhaps for the production of bronze ingots or for manufacturing new metal goods (S. Sherratt 1998:300)? Recall also that the Cape Gelidonya shipwreck ( $c$. 1200 BC) carried not only large amounts of bronze scrap, but also ingots of alloyed bronze (Bass 1967:78-82, 1991).

Discussion The evidence just cited for recycling in Sardinia, Cyprus and the Eastern Mediterranean could be multiplied endlessly. Because this evidence makes clear the ubiquity of recycling in the Mediterranean Late Bronze Age, we have to accept the reality that metals provenance studies will continue to be problematic (Pernicka et al. 1984; Karageorghis and Kassianidou 1999:185). And if we continue to rely on the application of these results in the interpretation of the wider archaeological record, we shall continue to be faced with other, equally intractable problems. For example, LIA indicates that about $30 \%$ of the analysed metal artifacts from Kition, Kalavasos Ayios Dhimitrios, Hala Sultan Tekke Vyzakia, Pyla

Kokkinkremos and Maa Palaeokastro were made of copper inconsistent with production from Cypriot ores (Stos-Gale and Gale 1994). Is this yet another case of coals to Newcastle? Or does it make more sense to see this phenomenon as one result of the role played by the 'high velocity' mixing and remelting of metals in a wide-reaching socio-economic system that had become dependent on an often 'irrational' inter-regional exchange for its continued existence (Liverani 1979; 1986; S. Sherratt 1999:176)?

Another problem leads to a similar dilemma. Why is it that nearly all analysed artifacts from the Late Bronze Age have an isotopic signature which differs from that of the copper oxhide ingots (Muhly 1998)? We have a situation in which most 'pure' copper ingots analysed appear to be consistent with production from Cypriot ores, and in which most mixed or alloyed artifacts analysed are said to be consistent with production from copper ores at Laurion in Greece. The problem is that there are no known ingots of 'Laurion copper' but rather of Cypriot, Anatolian or 
Knapp-Archaeology and Science/EJA

Sardinian copper, while the Laurion mines were most likely exploited in the Bronze Age for their lead ores. Even if the alloyed artifacts were made from Cypriot copper, which contains lead only at ppm (parts per million) levels, any admixture of tin with lead, or of recycled artifacts containing lead, e.g. from Laurion, would swamp the Cypriot lead isotopic signature, leading in part to the present conundrum. ${ }^{3}$ The simple answer is that the lead detected in these artifacts almost certainly did not come from the copper ore.

In such a situation, it is not unreasonable to suggest that the remarkably consistent composition of most copper oxhide ingots results from the production of multiple-sourced material which, over the course of the Late Bronze Age, had become pooled to the extent that the ingots' lead isotope signature could never reflect any single origin. Instead of blaming analytical techniques (or their practitioners) for failing to demonstrate this possibility, perhaps we should change the questions we are asking of provenance studies, and in particular of the role they play in understanding prehistoric metals production, trade and consumption. Analytical and archaeological evidence alike shows that trade contacts in the Bronze Age Mediterranean were multi-facetted (Knapp 1990: 1993; Knapp and Cherry 1994:123-55; A. Sherratt and E.S. Sherratt 1991; S. Sherratt 1999; various papers in Gale 1991a), and that oxhide ingots were distributed from Anatolia and Egypt in the East to Sardinia in the West, as well as North into the Black Sea. As suggested above, the amounts of scrap metal recovered from contemporaneous 'foundry' hoards, shipwrecks, and related contexts throughout the Mediterranean demonstrates that the reuse and recycling of metals during the Late Bronze-Early Iron Ages is no longer an issue for debate. Accordingly we should expect some scattering of lead isotope abundance ratios from the oxhide ingots. The ore deposits of Cyprus or Sardinia may have been the dominant contributors to the overall composition of most oxhide ingots but they may not have been the only ones. The existence of a common isotopic signature of copper ingots found throughout the Mediterranean then becomes indicative of widespread social and economic links within a dynamic and interdependent inter-regional system rather than just a signpost to which region(s) might have dominated or influenced the trading system.

If any of the copper oxhide ingots were ever produced from mixing or recycling metals and/or the pooling of different ore sources, they can no longer serve as the focus of Mediterranean provenance studies. Moreover, in social and economic terms, we should not set up a single product as representative of any cultural area, especially not one as extensive and varied as that which existed in the Mediterranean Bronze Age. Moreover, the exchange of goods - whether primary commodities like raw metals or added-value goods like pottery - should be perceived within the cultural context of the society that received and consumed them (S. Sherratt 1999:16869). Accordingly, the ingots may be seen as one aspect of the increasing commodification of metals during the Late Bronze Age, and as artifacts directly relevant to the study of Bronze Age production centres, trade mechanisms and consumption practices. Budd et al. (1995) observe that the koine in Late Bronze Age Mediterranean metalworking traditions included not just shared artifacts but also a shared material resource. The use of copper oxhide ingots as apparently standardized units of measure from Sardinia to the Black Sea and the Levant suggests 
Knapp-Archaeology and Science/EJA

that they served to give tangible expression to trade relationships in cumulative units of wealth. Their emergence as an exchange medium may therefore indicate the re-negotiation of both local and interregional socio-political relationships.

\section{Conclusions}

In his summary of the British Academy/Royal Society meeting on New Developments in Archaeological Science, Renfrew (1992:290-292) concluded :

Sometimes archaeologists and, I am afraid, archaeological scientists, rather readily take the view that the conclusions offered by the application of the methods of the natural sciences carry with them more weight than do those deriving from archaeology as such. It is pertinent, then, to remember that the findings of archaeological science have been reversed just as often.... That archaeological science should sometimes give the wrong answers, and that these can later be shown to be indeed erroneous, must be counted as one of the subject's great strengths.

Long-term collaboration between archaeologists and science-based archaeologists is essential if both fields are to move beyond their limited horizons and make useful contributions to understanding past social patterns, cultural practices and individual lives. The call for interdisciplinary collaboration and co-operation must be balanced by an equally strong appeal for archaeological scientists to accept that archaeological knowledge is often intangible and subject to change with increasing evidence or changes in interpretations.

Attempts to integrate scientific analyses with archaeological interpretation will continue to have diverse results - some wildly successful, others much less so. Sceptics like Dunnell and Chippindale must judge for themselves if the present study signals an optimistic, pessimistic or indifferent future. With regard to LIA, we cannot continue to interpret isotopic data in the manner initially envisaged by the relevant analytical programs (cf. Muhly 1995; Pernicka 1995). It seems that we have moved far beyond Muhly's greatest expectations about studying the production and distribution of copper oxhide ingots but, at the same time, we remain at the outer perimeter of understanding who mined the copper and how they lived; who produced the ingots and from which ores; and who orchestrated their distribution throughout an economic system spread across the Bronze Age Mediterranean world.

The technological knowledge required for the production of 'primary' commodities (Appadurai 1986:42) such as metals, fuels and grains was more readily accessible to people like miners, smelters and traders than was the knowledge required for producing luxury (or 'secondary') commodities. The circulation of both types of commodity across cultural, economic or spatial boundaries represents not just a physical process, but a social transaction that entangles givers and receivers in wider relations of dependence and alliance, of prestige and debt (Thomas 1991:123-24). In other words, luxury objects, prestige goods or even standardised bulk commodities have social meaning as well as economic value. The socio-cultural role of any 'commodity' must be assessed in the context of its technology and production, as well as its distribution and consumption. Changes in that role may represent long-term fluctuations in demand or value, or in socio-political relations (Renfrew 1986:152). If any recycling or pooling of metal went into producing the Mediterranean copper oxhide ingots of the Late Bronze Age, 
Knapp-Archaeology and Science/EJA

we should not regard this as just another contemporary (ecological) concern retrodicted onto the past. Rather, the notion of recycled metal made sound economic sense in the face of widespread demand and the increasing commodification of metals. At the same time, it exemplifies how social transactions of material products had broken down geographic and cultural barriers within a vast inter-regional, Mediterranean-wide economic system. 


\section{Endnotes}

Acknowledgments I wish to thank all the people who participated in the British Academy Group Research Project at the Universities of Cambridge and Oxford (1989-1993), in particular John F. Cherry, Richard Jones, and Noel Gale, without whose help and contributions this paper could never have been written. I must also thank all the contributors to the special issue of the Journal of Mediterranean Archaeology (8.1, June 1995) on Lead Isotope Analysis and Archaeology, in particular the authors of the lead article (Budd et al. 1995), which formed another point of reference for the present discussion. Students in the taught MSc and taught MPhil in Mediterranean Archaeology courses $(1998,1999)$ at the University of Glasgow reacted in diverse and helpful ways to some of the ideas expressed in this paper, and I am grateful for those reactions. I thank Sophia Antoniadou, Paul Budd, Vasiliki Kassianidou, James D. Muhly, Suzanne Young, and especially John F. Cherry for comments and critique of earlier drafts of this study. Finally, I wish to thank all my collaborators in the excavations at Politiko Phorades Michael Donnelly, Vasiliki Kassianidou, and Sven van Lokeren — for stimulating discussions and ideas concerning ancient mining and metallurgy.

1. My thanks to Michael Morsman, postgraduate student in Mediterranean Archaeology at the University of Glasgow, for drawing my attention to the material discussed in this section.

2. It must be made clear that Kassianidou does not think recycled metal was involved in the production of copper oxhide ingots (Karageorghis and Kassianidou 1999:185).

3. I am particularly grateful to Paul Budd, James Muhly and Richard Thomas for pointing out this issue and discussing it with me. 


\section{References:}

Appadurai, A. 1986. Toward an anthropology of things, in A. Appadurai (ed.), The Social Life of Things:3-63. Cambridge: Cambridge University Press.

Artzy, M. 1994. Incense, camels and collared rim jars: desert trade routes and maritime outlets in the second millennium. Oxford Journal of Archaeology 13:121-47.

Balmuth, M.S., \& R.F. Tylecote 1976. Ancient copper and bronze in Sardinia: excavations and analysis. Journal of Field Archaeology 3:195-201.

Balthazar, J.W. 1990. Copper and Bronze Working in Early through Middle Bronze Age Cyprus. Studies in Mediterranean Archaeology and Literature, Pocketbook 84. Göteborg: P.Åström's Förlag.

Barnes, I. L., R.H. Brill, E.C. Deal \& G.V. Piercy 1986. Lead isotope studies of some of the finds from the Serce Liman shipwreck, in J.S. Olin and M.J. Blackman (ed.), Proceedings of the 24th International Archaeometry Symposium:1-12. Washington, DC: Smithsonian Institute.

Barnes, I. L., W.T. Chase, L.L. Holmes, E.C. Joel, P. Meyers \& E.V. Sayre 1988. The technical examination, lead isotope determination, and elemental analysis of some Shang and Zhou Dynasty bronze vessels, in R. Maddin (ed.), The Beginnings and Use of Metals and Alloys:296-306. Cambridge, MA: MIT Press.

Bass, G.F. 1967. Cape Gelidonya: A Bronze Age Shipwreck. Transactions of American Philosophical Society 57.8. Philadelphia: American Philosophical Society.

Bass, G.F. 1991. Evidence of trade from Bronze Age shipwrecks. In N.H. Gale (ed.), Bronze Age Trade in the Mediterranean. Studies in Mediterranean Archaeology 90:69-82. Göteborg: P.Åström's Förlag.

Bass, G.F., C. Pulak, D. Collon \& J. Weinstein 1989. The Bronze Age shipwreck at Ulu Burun: 1986 campaign, American Journal of Archaeology 93:1-29.

Baxter, M.J. \& Gale, N.H. 1998. Testing for multivariate normality via univariate tests: a case study using lead isotope ratio data. Journal of Applied Statistics 25:671-83.

Begemann, F., S. Schmitt-Strecker, \& E. Pernicka 1989. Isotopic composition of $\mathrm{Pb}$ in early metal artifacts: results, possibilities and limitations, in A. Hauptmann, E. Pernicka and G.A. Wagner (ed.), Old World Archaeometallurgy. Der Anschnitt, Beiheft 8:269-78. Bochum: Deutsches Bergbaumuseum.

Budd, P., D. Gale, A.M. Pollard, R.G. Thomas \& P.A. Williams 1993. Evaluating lead isotope data: further observations. Archaeometry 35:241-6, 262-3.

Budd, P., A.M. Pollard, B. Scaife \& R.G. Thomas 1995. Oxhide ingots, recycling, and the Mediterranean metals trade, Journal of Mediterranean Archaeology 8:1-32.

Budd, P., R. Haggerty, A.M. Pollard, B. Scaife \& R.G. Thomas 1996. Rethinking the quest for provenance. Antiquity 70:168-74.

Budd, P., \& T. Taylor 1995. The faerie smith meets the bronze industry: magic versus science in the interpretation of prehistoric metal-making. World Archaeology 27:133-143.

Cherry, J.F. \& A.B. Knapp 1991. Quantitative provenance studies and Bronze Age trade in the Mediterranean: some preliminary reflections, in N.H. Gale (ed.) Bronze Age Trade in the Mediterranean. Studies in Mediterranean Archaeology 90:92-119. Göteborg: P. Åström's Förlag.

Chippindale, C. 1994. Editorial. Antiquity 68/259:191-9.

Demirci, S., A.M. Özer and G.D. Summers (eds) 1996. Archaeometry 94. The Proceedings of the 29th International Symposium on Archaeometry. Ankara: Türkiye Bilimsel ve Teknik Arastirma Kurumu. 
Knapp-Archaeology and Science/EJA

Dobres, M.-A., \& C.R. Hoffman 1994. Social agency and the dynamics of prehistoric technology. Journal of Archaeological Method and Theory 1:211-58.

Dunnell, R. 1992. Is a scientific archaeology possible?, in L. Embree (ed.), Metaarchaeology: Reflections by Archaeologists and Philosophers: 75-97. Dordrecht: Kluwer.

Dunnell, R. 1993 Why archaeologists don't care about archaeometry, Archeomaterials 7:161-5.

Fahrquhar, R., \& V. Vitali 1989. Lead isotope measurements and their application to Roman lead and bronze artifacts from Carthage, in S.J. Fleming and H.R. Schenck (ed.), MASCA Research Papers in Science and Archaeology 6:39-45. Philadelphia: MASCA, University Museum.

Gale, N.H. 1989a Lead isotope analyses applied to provenance studies - a brief review, in In. Maniatis (ed.), Archaeometry: Proceedings of the 25th International Symposium, 469-502. Elsevier: Amsterdam.

Gale, N.H. 1989b. Archaeometallurgical studies of Late Bronze Age oxhide copper ingots from the Mediterranean region, in A. Hauptmann, E. Pernicka, and G.A. Wagner (ed.), Old World Archaeometallurgy. Der Anschnitt, Beiheft 7:247-68. Bochum: Deutsches Bergbau-Museum.

Gale, N.H. 1991a. (ed.) Bronze Age Trade in the Mediterranean. Studies in Mediterranean Archaeology 90. Göteborg: P. Åström's Förlag.

Gale, N.H. 1991b. Copper oxhide ingots: their origin and their place in the Bronze Age metals trade in the Mediterranean. In N. H. Gale (ed.), Bronze Age Trade in the Mediterranean. Studies in Mediterranean Archaeology 90:197-239. P. Åström's Förlag: Göteborg.

Gale, N.H., \& S. Stos-Gale 1982a. Bronze and copper sources in the Mediterranean: a new approach, Science 216:11-19.

Gale, N.H., \& S. Stos-Gale 1982b. Lead and silver in the ancient Aegean. Scientific American 244(6):176-192.

Gale, N.H., \& S. Stos-Gale 1987. Oxhide ingots from Sardinia, Crete and Cyprus and the Bronze Age copper trade: new scientific evidence, in M.S. Balmuth (ed.), Studies in Sardinian Archaeology 3: Nuragic Sardinia and the Mycenaean World. British Archaeological Reports International Series 387:135-78. Oxford: British Archaeological Reports.

Gale, N.H., \& S. Stos-Gale 1992. Evaluating lead isotope data: comments I, Archaeometry 34:311-7.

Gale, N.H., \& S. Stos-Gale 1995. Comment on 'Oxhide ingots, recycling, and the Mediterranean metals trade,' Journal of Mediterranean Archaeology 8:33-41.

Gale, N.H., Z.A. Stos-Gale, G. Maliotis and N. Annetts 1997. Lead isotope data from the Isotrace Laboratory: Oxford. Archaeometry data base 4, ores from Cyprus, Archaeometry 39, 237-45.

Given, M., A.B. Knapp, N. Meyer, T.E. Gregory, V. Kassianidou, J. Noller, L. Wells, N. Urwin, and H. Wright 1999. The Sydney Cyprus Survey Project: An Interdisciplinary Investigation of Long-Term Change in the North Central Troodos, Cyprus. Journal of Field Archaeology 26: 19-39.

Hall, M. 1995. Comments on 'Oxhide ingots, recycling, and the Mediterranean metals trade,' Journal of Meditrranean Archaeology 8:42-44.

Hodder, I.A. 1991. Interpretive archaeology and its role. American Antiquity 56:7-18.

Hosler, D., \& A. Macfarlane 1996. Copper sources, metal production, and metals trade in Late Postclassic Mesoamerica. Science 273 (27 Sept 1996) 1819-24.

Jones, R.E. 1986. Greek and Cypriot Pottery: A Review of Scientific Studies. British School at Athens, Fitch Laboratory, Occasional Paper 1. Athens: British School at Athens.

Jones, R.F.J. 1988. Questions, answers and the consumer in archaeological science, in E.A.

Slater and J.O Tate (ed.), Science and Archaeology, Glasgow 1987. British Archaeological Reports, British Series 196(i):286296. Oxford: British Archaeological Reports. 
Knapp-Archaeology and Science/EJA

Karageorghis, V., \& V. Kassianidou 1999. Metalworking and recycling in Late Bronze Age cyprus - the evidence from Kition. Oxford Journal of Archaeology 18:171-188.

Kassianidou, V., \& H.G. Wright 1996. SCSP 1995: Agrokipia-Kriadis mine (Unit 2013) and Mitsero-Sykamies slag heap (Unit 2009). In Knapp, A.B., \& M. Given The Sydney Cyprus Survey Project (SCSP) — third season (1995). Report of the Department of Antiquities, Cyprus: 316-323.

Keswani, P.S. 1993. Models of local exchange in Late Bronze Age Cyprus. Bulletin of the American Schools of Oriental Research 292:73-83.

Keswani, P.S., \& A.B. Knapp 1997. Bronze Age boundaries and social exchange in the northwest Cyprus. Paper presented at the Annual Meeting of the American Schools of Oriental Research, Napa, CA. (18 November 1997).

Killick, D. 1992. Review of J. Henderson (ed.), Scientific Analysis in Archaeology. Oxford University Committee for Archaeology, Monograph 19 (Oxbow Books, Oxford: 1989), in Journal of Field Archaeology 19, 117-21.

Killick, D., \& S.M.M. Young 1997. Archaeology and archaeometry: from casual dating to a meaningful relationship?, Antiquity 71/273:518-24.

Kintigh, K.W. 1987. Quantitative methods designed for archaeological problems, in M. Aldenderfer (ed.), Quantitative Research in Archaeology: Progress and Prospects: 126-34. Newbury Park, CA: Sage Publications.

Knapp, A.B. 1986. Copper Production and Divine Protection: Archaeology, Ideology and Social Complexity on Bronze Age Cyprus. Studies in Mediterranean Archaeology, Pocketbook 42. Göteborg: P. Åström's Förlag.

Knapp, A.B. 1988. Hoards D'Oeuvres: of metals and men on Bronze Age Cyprus. Oxford Journal of Archaeology 7:147-176.

Knapp, A.B. 1990. Entrepreneurship, ethnicity, exchange: Mediterranean inter-island relations in the Late Bronze Age, Annual of the British School at Athens 85:115-53.

Knapp, A.B. 1993. Thalassocracies in Bronze Age eastern Mediterranean trade: making and breaking a myth, World Archaeology 24:332-347.

Knapp, A.B. 1996. Archaeology without gravity: postmodernism and the past. Journal of Archaeological Method and Theory 3:127-158.

Knapp, A.B. 1997. The Archaeology of Late Bronze Age Cypriot Society: The Study of Settlement, Survey and Landscape. Department of Archaeology, University of Glasgow, Occasional Paper 4. Glasgow.

Knapp, A.B., \& J.F. Cherry 1991. Archaeological science, statistics, and cultural solutions: trade patterns in the Bronze Age eastern Mediterranean, in E. Pernicka and G.A. Wagner (ed.), Archaeometry 90:183-98. Basel: Birkhäuser Verlag.

Knapp, A.B., \& J.F. Cherry 1994. Provenance Studies and Bronze Age Cyprus: Production, Exchange, and Politico-Economic Change. Monographs in World Archaeology 21. Madison, WI: Prehistory Press.

Knapp, A.B., \& M. Given 1996. The Sydney Cyprus Survey Project (SCSP) — third season (1995). Report of the Department of Antiquities, Cyprus: 295-366.

Knapp, A.B., M. Donnelly \& L. Kassianidou 1998. Excavations at Politiko Phorades - 1997. Report of the Department of Antiquities, Cyprus: 247-268.

Knapp, A.B., L. Kassianidou \& M. Donnelly 1999. Excavations at Politiko Phorades - 1998. Report of the Department of Antiquities, Cyprus: (in press).

Knapp, A.B., J.D. Muhly \& P.M. Muhly 1988. To hoard is human: the metal deposits of LC IICLC III. Report of the Department of Antiquities, Cyprus:233-62.

Knapp, A.B., V. Pigott And E. Herbert (eds) 1998. Social Approaches to an Industrial Past: The Archaeology and Anthropology of Mining. London: Routledge. 
Knapp - Archaeology and Science/EJA

Lavender, D. 1962. The Story of Cyprus Mines Corporation. Huntington Library: San Marino, CA. Lightfoot, K.G. 1995 Culture contact studies: redefining the relationship between prehistoric and historical archaeology. American Antiquity 60:199-217.

Liverani, M. 1986. La ceramica e i testi: commercio miceneo e politica orientale. In M. Marazzi, S. Tusa and L. Vagnetti (eds), Traffici Micenei nel Mediterraneo, pp. 405-12 Taranto: Istituto per la Storia e l'Arch. della Magno Grecia.

Liverani, M. (translated M.I. Jaffe) 1979. Irrational elements in the Amarna trade. Monographs on the Ancient Near East 1(5):21-33. Malibu: Undena.

Lo Schiavo, F. 1981. Economia e societa nell'eta dei nuraghi. In E. Atzeni, F. Barreca, m.1. Ferrarese-Ceruti, E. Contu, G. Lilliu, F. Lo Schiavo, F. Nicosia, and E. Equini Schneider (eds), Ichnussa: La Sardegna dall Origini all'Eta Classica, 255-347. Milano: Garzanti.

Lo Schiavo, F. 1989. Early Metallurgy in Sardinia: copper ox-hide ingots. In A. Hauptmann, E. Pernicka, and G.A. Wagner (eds), Old World Archaeometallurgy. Der Anschnitt 7:33-38. Bochum: Deutschen Bergbau-Museums.

Lo Schiavo, F. 1998. Sardinian oxhide ingots 1998. In T. Rehren, A. Hauptmann and J. D. Muhly (eds), Metallurgica Antiqua: In Honour of Hans-Gert Bachmann and Robert Maddin. Der Anschnitt, Beiheft 8:99-112. Bochum: Deutsches Bergbaumuseum.

Lo Schiavo, F., R. Maddin, J. Merkel, J.D. Muhly, \& T. Stech 1990. Metallographic and Statistical Analyses of Copper Ingots from Sardinia. Ministero per i Beni Culturali e Ambientali, Soprintendenza ai Beni Archaeologici per le Province de Sassari e Nuoro, Quaderni 17. Ozieri: Torchietto.

Lo Schiavo, F., T. Stech, R. Maddin, \& J.D. Muhly 1987. Nuragic metallurgy in Sardinia; second preliminary report. In M.S. Balmuth (ed.), Studies in Sardinian Archaeology 3. BAR International Series 387:179-187. Oxford: British Archaeological Reports.

McGovern, P.E. 1995. Science in archaeology: a review, American Journal of Archaeology 99:79142.

Maddin, R. 1988. Technical studies - early use of metals, in E.V. Sayre, P. Vandiver, J. Druzik, and C. Stevenson (ed.), Materials Issues in Art and Archaeology. Materials Research Society Symposium Proceedings 123:171-81. Pittsburgh: Materials Research Society.

Maddin, R. 1989. The copper and tin ingots from the Kas shipwreck, in A. Hauptmann, E. Pernicka and G.A. Wagner (ed.), Old World Archaeometallurgy. Der Anschnitt 7:99-105. Bochum: Deutsches Bergbau-Museums.

Muhly, J.D. 1977. The copper ox-hide ingots and the Bronze Age metals trade, Iraq 39:73-82.

Muhly, J.D. 1985a. Lead isotope analysis and the problem of lead in Cyprus, Report of the Department of Antiquities, Cyprus: 78-82.

Muhly, J.D. 1985b. The Late Bronze Age in Cyprus: a 25 year retrospect, in V.Karageorghis (ed.), Archaeology in Cyprus 1960-1985:20-46. Nicosia: Leventis Foundation.

Muhly, J.D. 1989. The organisation of the copper industry in Late Bronze Age Cyprus, in E.J. Peltenburg (ed.), Early Society in Cyprus: 298-314. Edinburgh: Edinburgh University Press.

Muhly, J.D. 1991. The development of copper metallurgy in Late Bronze Age Cyprus, in N. H. Gale (ed.), Bronze Age Trade in the Mediterranean. Studies in Mediterranean Archaeology 90:180-96. Göteborg: P. Åström's Förlag.

Muhly, J.D. 1995. Lead isotope analysis and the archaeologists, Journal of Meditrranean Archaeology 8:54-8.

Muhly, J.D. 1998. Metals and metallurgy: using modern technology to study ancient technology. In Ancient Greek Technology: Proceedings of the First International Conference on Ancient Greek Technology (Thessaloniki, 4-7 Sept. 1997), 27-33. Thessaloniki: Technology Museum. 
Knapp-Archaeology and Science/EJA

Muhly, J.D., R. Maddin, \& V. Karageorghis (eds) 1982. Acta of the International Archaeological Symposium: Early Metallurgy in Cyprus, 4000-500 B.C. Nicosia: Pierides Foundation.

Muhly, J.D., R. Maddin, \& T. Stech 1988. Cyprus, Crete and Sardinia: copper oxhide ingots and the metals trade, Report of the Department of Antiquities, Cyprus: 281-98.

Muhly, J.D., \& T. Stech 1990. Final Observations, in F. Lo Schiavo et al., Metallographic and Statistical Analyses of Copper Ingots from Sardinia. Ministero per i Beni Culturali e Ambientali, Soprintendenza ai Beni Archaeologici per le Province de Sassari e Nuoro, Quaderni 17:201-21. Ozieri: Torchietto.

Needham, S.P., M.N. Leese, D.R. Hook, \& M.J. Hughes 1989. Developments in the Early Bronze Age metallurgy of southern Britain, World Archaeology 20:383-402.

Olin, J. (ed.) 1982. Future Directions in Archaeometry: A Round Table. Washington, DC: Smithsonian Institute Press.

Pernicka, E. 1987. Erzlagerstätten in der Ägäis unde ihre Ausbeutung im Altertum: geochemische Untersuchungen zur Herkunftsbestimmung archäologischer Metallobjekte, Jahrbuch des Römisch-Germanisches Zentralmuseum 34:607-713.

Pernicka, E. 1995. Crisis or catharsis in lead isotope analysis?, Journal of Meditrranean Archaeology 8:59-64.

Pernicka, E., F. Begemann, S. Schmitt-Strecker, \& A.P. Grimanis 1990. On the composition and provenance of metal artifacts from Poliochni on Lemnos, Oxford Journal of Archaeology 9:263-98.

Pernicka, E., T.C.Selliger, G.A.Wagner, F.Begeman, S. Schmitt-Strecker, S. Eibner, O. Oztunali, \& I. Baranyi 1984. Archaeometallurgische Untersuchungen in Nordwestanatolien. Jahrbuch der Römisch-Germanischen Zentralmuseums 31:533-599.

Pollard, A.M. 1983. A critical study of multivariate methods as applied to provenance data, in A. Aspinall and S.E. Warren (ed.), Proceedings of the 22nd Archaeometry Symposium: 56-66. Bradford: University of Bradford.

Pollard, A.M. 1992. (ed.) New Developments in Archaeological Science. Proceedings of the British Academy 77. London: British Academy.

Pollard, A.M. 1995. Why teach Heisenberg to archaeologists?, Antiquity 69/263:242-7.

Preucel, R.W. 1991. Introduction, in R.W. Preucel (Ed), Processual and Postprocessual Archaeologies: Multiple Ways of Knowing the Past. Center for Archaeological Investigations Occasional Paper 10:1-14. Carbondale, IL: Center for Archaeological Investigation.

Preucel, R.W. 1995. The postprocessual condition, Journal of Archaeological Research 3:147-75.

Pulak, C. 1995. Das Schiffswrack von Uluburun, Zaberns Bildbände zur Archäologie 23:43-58.

Pulak, C. 1997. The Uluburun shipwreck, in S. Swiny, R. Hohlfelder \& Helena W. Swiny (ed.), Res Maritimae: Cyprus and the Eastern Mediterranean from Prehistory through the Roman Period. Cyprus American Archaeological Research Institute, Monograph 1:233-62. Atlanta: ASOR/ Scholars Press.

Read, D.W. 1989. Intuitive typology and automatic classification: divergence or full circle? Journal of Anthropological Archaeology 8:158-188.

Reedy, C.L., \& T.J. Reedy 1988. Lead isotope analysis for provenance studies in the Aegean region: a re-evaluation in E.V. Sayre, P.B. Vandiver, J. Druzik and C. Stevenson (ed.), Materials Issues in Art and Archaeology. Materials Research Society Symposium Proceedings 123:65-70. Pittsburgh: Materials Research Society.

Renfrew, A.C. 1986. Varna and the emergence of wealth in prehistoric Europe, in A. Appadurai (ed.), The Social Life of Things: 141-68. Cambridge: Cambridge University Press. 
Knapp-Archaeology and Science/EJA

Renfrew, A.C. 1992. Meeting summary: the identity and future of archaeological science, in A. M. Pollard (ed.), New Developments in Archaeological Science. Proceedings of the British Academy 77:285-93. London: British Academy.

Sayre, E.V., K.A. Yener, E.C. Joel, \& I.L. Barnes 1992. Statistical evaluation of the presently accumulated lead isotope data from Anatolia and the surrounding regions, Archaeometry 34:73-105.

Sayre, E.V., K.A. Yener \& E.C. Joel 1995. Comments on 'Oxhide ingots, recycling, and the Mediterranean metals trade,' Journal of Meditrranean Archaeology 8:45-53.

Scaife, B., P. Budd, J.G. McDonnell, A.M. Pollard and R.G. Thomas 1996. A reappraisal of statistical techniques used in lead isotope analysis, in S. Demirici, A.M. Özer and G.D. Summers (eds), Archaeometry 94. The Proceedings of the 29th International Symposium on Archaeometry: 301-307. Ankara: TBITAK.

Schiffer, M.B. 1996 Some relationships between behavioral and evolutionary archaeologies. American Antiquity 61:643-62.

Seeliger, T.C., E.Pernicka, G.A.Wagner, F.Begemann, S.Schmitt-Strecker, C.Eibner, O. Öztunali, and I.Baranyi 1985. Archaometallurgische Untersuchungen in Nord- und Ostanatolien, Jahrbuch des Römisch-Germaniscehn Zentralmusuems 32:597-659.

Shanks, M., \& I.A. Hodder 1995. Processual, postprocessual and interpretive archaeologies. In I. Hodder, M. Shanks, A. Alexandri, V Buchli, J. Carman, J. Last and G. Lucas (eds), Interpreting Archaeology: Finding Meaning in the Past, pp. 3-29. London: Routledge.

Shanks, M., \& R. H. McGuire 1996. The craft of archaeology. American Antiquity 61:75-88.

Sherratt, A.G. 1994. Core, periphery and margin: perspectives on the Bronze Age. In S. Stoddart and C. Mathers (eds), Development and Decline in the Bronze Age Mediterranean. Sheffield Archaeological Monograph 8:335-45. Sheffield: J.R. Collis Publications.

Sherratt, A.G., \& E.S. Sherratt 1991. From luxuries to commodities: the nature of Mediterranean Bronze Age trading systems, in N.H. Gale (ed.), Bronze Age Trade in the Mediterranean.

Studies in Mediterranean Archaeology 90:351-86. Göteborg: P. Åström's Förlag.

Sherratt, S. 1998. "Sea Peoples" and the economic structure of the late second millennium in the eastern Mediterranean. In S. Gitin, A. Mazar and E. Stern (eds), Mediterranean Peoples in Transition: Thirteenth to Tenth Centuries BCE, pp. 292-313. Jerusalem: Israel Exploration Society.

Sherratt, S. 1999. E pur si muove: pots, markets and values in the second millennium Mediterranean. In J.P. Crielaard, V. Stissi \& G.J. van Wijngaarden (eds), The Complex Past of Pottery: Production, Circulation and Consumption of Mycenaean and Greek Pottery, pp. 163-211. Amsterdam: Gieben.

Smith, J.S. 1992-93. The Pylos JN series. Minos 227-28:167-259.

South, A.K. 1989. From copper to kingship: aspects of Bronze Age society viewed from the Vasilikos Valley. In E.J. Peltenburg (ed.), Early Society in Cyprus, pp. 315-24. Edinburgh: Edinburgh University Press.

Stech, T. 1982. Urban metallurgy in Late Bronze Age Cyprus, in J.D. Muhly, R. Maddin, and V. Karageorghis (ed.), Early Metallurgy in Cyprus, 4000-500 BC: 105-15. Pierides Foundation: Nicosia.

Stos-Gale, Z.A., \& N.H. Gale 1994. Metals, in A. B. Knapp and J. F. Cherry, Provenance Studies and Bronze Age Cyprus: Production, Exchange, and Politico-Economic Change. Monographs in World Archaeology 21:92-121. Madison, WI: Prehistory Press.

Stos-Gale, Z.A., Maliotis, G., Gale, N.H. , \& Annetts, N. 1997. Lead isotope characteristics of the Cyprus copper ore deposits applied to provenance studies of copper oxhide ingots, Archaeometry 39:83-123. 
Knapp-Archaeology and Science/EJA

Thomas, N. 1991. Entangled Objects: Exchange, Material Culture, and Colonialism in the Pacific. Cambridge, MA: Harvard University Press.

Toulmin, S. 1977. From form to function: philosophy and history of science in the 1950s and now, Daedalus 106(3):143-62.

Trigger, B.G. 1988. Archaeology's relations with the physical and biological sciences: a historical review, in R.M. Fahquhar, R.G.V. Hancock, and L.A. Pavlish (ed.), Proceedings of the 26th International Archaeometry Symposium: 1-9. Toronto: Archaeometry Laboratory, Physics Department, University of Toronto.

Trigger, B.G. 1991. Post-processual developments in Anglo-American archaeology, Norwegian Archaeological Review 24(2):65-76.

Tylecote, R.F., M.S. Balmuth, \& R. Massoli-Novelli 1984. Copper and bronze metallurgy in Sardinia. In M. Balmuth (ed.), Studies in Sardinian Archaeology 1:115-162. Ann Arbor: University of Michigan Press.

Vaughan, S.J. 1995. Observations from an Aegean perspective on the relationship of archaeology and science as reflected in the study of ancient pottery, in C. Morris and A. Peatfield (ed.), Klados: Essays in honour of J.N. Coldstream. Bulletin of the Institute of Classical Studies, Supplement 63:261-70. London: Institute of Classical Studies.

Webb, J.M., \& D. Frankel 1994. Making an impression: storage and surplus finance in Late Bronze Age Cyprus, Journal of Mediterranean Archaeology 7:5-26.

Young, S.M.M., A.M. Pollard, P. Budd and R.A. Ixer (ed.) 1999. Metals in Antiquity. British Archaeological Reports, International Series 792. Oxford: Archaeopress.

Zaccagnini, C. 1986. Aspects of copper trade in the eastern Mediterranean during the Late Bronze Age. In M. Marazzi, S. Tusa and L. Vagnetti (eds), Traffici Micenei nel Mediterraneo: Problemi Storici e Documentazione Archeologica. Magna Graecia 3:413424. Taranto: Istituto per la storia e l'archeologia della Magna Grecia. 